\title{
Comparing the use of qPCR on isolated smallmouth bass (Micropterus dolomieu) and rainbow trout (Oncorhynchus mykiss) hepatocytes for estrogen screening
}

\author{
Emily Breana Chambers \\ West Virginia University
}

Follow this and additional works at: https://researchrepository.wvu.edu/etd

\section{Recommended Citation}

Chambers, Emily Breana, "Comparing the use of qPCR on isolated smallmouth bass (Micropterus dolomieu) and rainbow trout (Oncorhynchus mykiss) hepatocytes for estrogen screening" (2010). Graduate Theses, Dissertations, and Problem Reports. 2951.

https://researchrepository.wvu.edu/etd/2951

This Thesis is protected by copyright and/or related rights. It has been brought to you by the The Research Repository @ WVU with permission from the rights-holder(s). You are free to use this Thesis in any way that is permitted by the copyright and related rights legislation that applies to your use. For other uses you must obtain permission from the rights-holder(s) directly, unless additional rights are indicated by a Creative Commons license in the record and/ or on the work itself. This Thesis has been accepted for inclusion in WVU Graduate Theses, Dissertations, and Problem Reports collection by an authorized administrator of The Research Repository @ WVU. For more information, please contact researchrepository@mail.wvu.edu. 


\title{
Comparing the use of qPCR on isolated smallmouth bass (Micropterus dolomieu) and rainbow trout (Oncorhynchus mykiss) hepatocytes for estrogen screening
}

\author{
Emily Breana Chambers \\ Thesis submitted to the Davis College of Agriculture, \\ Natural Resources and Design at West Virginia University \\ in partial fulfillment \\ of the requirements for the degree of
}

Master of Science

in

Wildlife and Fisheries Resources

\author{
Patricia Mazik, Ph.D., Chair \\ Stuart Welsh, Ph.D. \\ Kyle Hartman, Ph.D. \\ Division of Forestry and Natural Resources
}

Morgantown, West Virginia

2010

Keywords: vitellogenin, POCIS, smallmouth bass, rainbow trout, endocrine disruption, wastewater effluent, Potomac River 


\section{ABSTRACT \\ Comparing the use of qPCR on smallmouth bass (Micropterus dolomieu) and rainbow trout (Oncorhynchus mykiss) hepatocytes for estrogen screening}

\section{Emily B. Chambers}

Exposure of fish to estrogenic endocrine disrupting chemicals (EEDCs) is believed to be a contributing factor of intersex (the presence of immature oocytes in the testes) and fish kills in the Potomac and Shenandoah Rivers. EEDCs are often seen in the effluent of wastewater treatment plants. A simple and common way to look at the estrogenicity of water samples is to deploy Passive Organic Chemical Integrative Samplers (POCIS) and extract the hydrophilic compounds from the filters with methanol. Samplers were deployed upstream and downstream of two wastewater treatment plants, one on the Conococheague River and one on the Monocacy River, both of which are in Maryland. For comparison purposes, one POCIS was deployed in Blue Plains, just outside of Washington, D.C. and one POCIS was deployed at a control site in a closed pond at the National Fish Health Research Laboratory in Kearneysville, WV. Primary hepatocytes from rainbow trout (Oncorhynchus mykiss) and smallmouth bass (Micropterus dolomieu) were isolated to compare vitellogenin induction upon exposure to 17- $\beta$ estradiol. Smallmouth bass hepatocytes yielded low concentrations of RNA and qPCR was unsuccessful. Male rainbow trout showed low vitellogenin induction levels at high concentrations of 17- $\beta$ estradiol and no induction at low concentrations. Female rainbow trout hepatocytes showed vitellogenin induction during exposure to 17- $\beta$ estradiol at high and low concentrations. Rainbow trout hepatocytes were used to screen for estrogenic compounds from the extracts of the deployed water samplers also using vitellogenin induction as an endpoint. Male rainbow trout hepatocytes showed no vitellogenin induction. Female rainbow trout hepatocytes exposed to samples showed no statistically significant differences in vitellogenin induction. 


\section{Acknowledgments}

First and foremost, I would like to thank my committee members: Dr. Pat Mazik, who stood behind me and encouraged me when I needed it most, Dr. Stuart Welsh, for guidance and support, and Dr. Kyle Hartman, for stepping in and giving me insight. For their patience and direction, I am eternally grateful.

Also, my sincerest gratitude goes to Jim Hedrick and the West Virginia Department of Natural Resources for supplying me with many smallmouth bass, to Jim Everson at the United States Department of Agriculture National Center for Cool and Cold Water Aquaculture for the male rainbow trout, and to United States Fish and Wildlife Service for the POCIS samples.

Special thanks to Dr. Chris Ottinger, Dr. Laura Robertson, Edward McGinley, Stephanie Gatrell, Dr. Kenneth Blemings, Dr. Vicki Blazer, Dr. Luke Iwanowicz and the other scientists at the National Fish Health Research Laboratory at Leetown Science Center for all their assistance and knowledge.

And, of course, great thanks to my family and friends for always being there. I could not and would not be here without every single one of you.

I would also like to especially point out the unconditional love and support of Roger Dodger Chambers (the SB, el Nacion, my big-headed boy). He steadfastly saw me through all of this, never failing to be right by my side when I reached my hand out for help. The entirety of this work is dedicated to him. 


\section{Table of Contents}

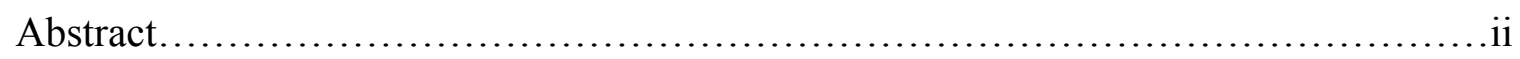

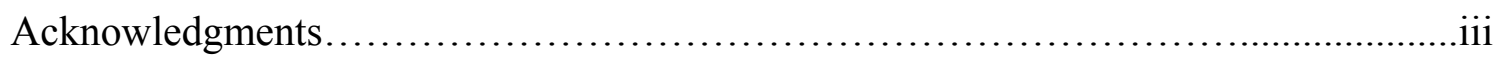

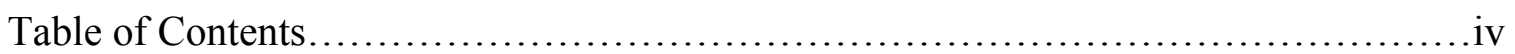

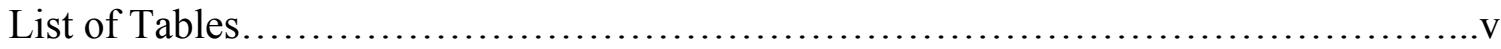

List of Figures...........................................................

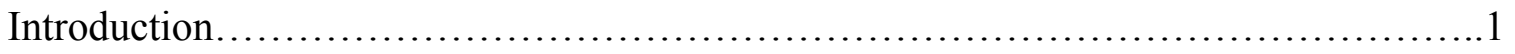

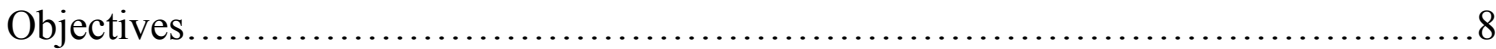

Materials and Methods..........................................................

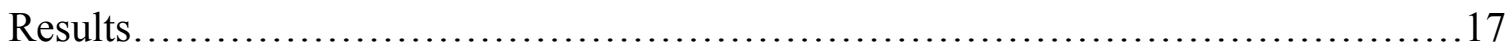

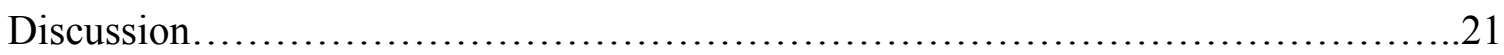

Literature Cited ...........................................................28 


\section{List of Tables}

Table 1: Polar organic chemical integrative samplers extract key.................... 36

Table 2: cDNA synthesis master mix formulation................................. 37

Table 3: Quantitative polymerase chain reaction master mix formulation...............38

Table 4: Estrogenic compounds found from chemical analysis of polar organic chemical integrative sampler extracts.................................... 39 


\section{List of Figures}

Figure 1: Map of POCIS deployment experimental sites........................40

Figure 2: Images of smallmouth bass hepatocytes in culture ..........................41

Figure 3: Images of rainbow trout hepatocytes in culture ..........................42

Figure 4: Boxplot of ratios of 2005 POCIS samples...........................43

Figure 5: Boxplot of ratios of 2006 POCIS samples.............................44 


\section{Introduction}

The study of estrogenic endocrine disrupting chemicals (EEDCs) as an emerging contaminant in waterways is gaining recognition, not only in the research field but also in the public eye (Jobling and Tyler, 2003). EEDCs are found in urban and rural waterways, and possible sources include agricultural runoff and wastewater treatment plant effluent among others. These compounds are from a family of chemicals including both synthetic and natural substances that are able to mimic, inhibit, or amplify the actions of the normal estrogens involved in cellular signaling for the endocrine system (Arcand-Hoy et al., 1998).

Natural estrogens are a family of three steroid hormones found in females of all vertebrate species: estriol, estradiol, and estrone, and they are known to stimulate the estrous cycle (Tribe and Eraut, 1979). These compounds are primarily secreted by the ovary and bind to estrogen receptors found throughout the body to allow for normal endocrine system actions. Estrogen synthesis in the ovary occurs through a biofeedback mechanism called the hypothalamus-pituitary-gonadal axis (HPG). The HPG axis of teleost fishes is, in general, similar to that found in other oviparous vertebrates. The principal components of the axis include the hypothalamus and the pituitary gland in the brain, the gonads (ovaries, in this case), and the liver. The initiation of the hormonal fluctuations that are responsible for maturation and spawning in fish are in response to environmental stimuli, such as the seasonal changing pattern of day length, and rise in water temperature, and internal stimuli, such as nutritional status and endogenous rhythms. When conditions are right, neurosecretory cells of the hypothalamus begin to produce and release gonadotropin- 
releasing hormone $(\mathrm{GnRH})$. Once $\mathrm{GnRH}$ is secreted and passed down neuronal connections between the hypothalamus and pituitary, it acts to stimulate the gonadotropic cells to secrete gonadotropin hormone (GTH) and growth hormone (GH) into the bloodstream. Through the bloodstream, GTH and GH reach gonadal tissues and bind with specific receptors on the ovary. The binding of these hormones to their receptors leads to increased production and secretion of sex steroid estrogen (Jobling, 1995). Estrogen-mediated receptors (ER) have been found in the kidney, intestine, liver, gonads, and heart of fish species (Anglade et al., 1994; Munoz-Cueto et al., 1999; Soccorro et al., 2000; Tan et al., 1996; Tchoudakova et al., 1999). There are two definitively known estrogen receptors in fish: ER $\alpha$ and ER $\beta$. The ERs have been characterized in several teleost fish, including rainbow trout (Oncorhynchus mykiss) (Pakdel et al., 1990), tilapia (Oreochromis aureus) (Tan et al., 1995), channel catfish (Ictalurus punctatus) (Xia et al., 1999), gilthead seabream (Sparus aurata) (Munoz-Cueto et al., 1999; Socorro et al., 2000) and goldfish (Carassius auratus) (Tchoudakova et al., 1999). Once estrogens in the bloodstream bind to estrogen receptors on the liver, vitellogenin is synthesized within the liver and transported by blood to the ovary where it is taken up by oocytes, cleaved into the final egg-yolk proteins (lipovitellin and phosvitin) and deposited as yolk granules or platelets (Wallace, 1978). Vitellogenin, a glycolipophosphoprotein that is the precursor protein for egg yolk, is typically dormant in male fish, but upon exposure to estrogens or estrogen mimics it can be induced and expressed. The expression of vitellogenin (vtg) in male fish is known to be a common biomarker indicating exposure to EEDCs (Cheek et al., 2001; Sumpter and Jobling, 1995). 
The list of EEDCs is numerous and includes natural and synthetic hormones as well as organochlorines, polycyclic aromatic hydrocarbons, dioxins, byproducts of plastic manufacturing, heavy metals, etc. (Arcand-Hoy et al., 1998). Wildlife exposure to endocrine-disrupting chemicals in the environment has also been associated with reduced fertility in fish (Leatherland, 1992), shellfish (Gibbs et al., 1988), and mammals (Reijnders, 1986); abnormal thyroid function in birds (Moccia et al., 1986) and fish (Moccia et al., 1981); decreased hatching success in birds (Kubiak et al., 1989), fish (Mac et al., 1988) and turtles (Bishop et al., 1991); demasculinization and feminization of male fish (Munkittrick et al., 1991), birds (Fry and Toone, 1981); defeminization and masculinization of female fish (Davis and Bortone, 1992), gastropods (Ellis and Pattisina, 1990), and birds (Fry and Toone, 1981); and changes in immune function in birds (Erdman, 1988) and mammals (Martineau et al., 1988). In the Potomac River and nearby drainages endocrine disruptors have been linked to intersex, which is defined as the presence of both male and female characteristics in an organism that is known to be exclusively male or female, or gonochoristic (Blazer et al., 2007).

In addition to intersex, it has also been proposed that EEDCs are linked to fish kills in the Potomac River watershed (Blazer et al., 2007). After intersex was first described in smallmouth bass in the Potomac River in 2001, fish kills and skin lesions were seen on a number of fish species, including smallmouth bass, observed in the South Branch of the Potomac River in the summer and fall of 2002. It is believed that EEDCs are not a direct causative agent for fish kills, but that fish exposure to EEDCs is a stressor, thereby leaving the fish more susceptible to disease (Dunier, 1997). 
The families of compounds and chemicals already identified as EEDCs have chemical structures that are not only vastly different from each other, but can also be vastly different from the natural estrogens whose pathways they are disrupting.

Structurally, estrogens are composed of three aromatic rings, but there is such a lack of structural similarity between normal estrogens and EEDCs that it is very difficult to pinpoint any structural trends of the chemicals that are causing problems. As more EEDCs are being identified, it is being realized that the list of chemicals is extensive and numerous. With this realization, current research is limited because there are many EEDCs, and trying to discern their potential interactions is difficult. There are multiple tissues that have estrogen receptors associated with them, so the effects of EEDCs within the pathways of the endocrine system are unknown (Larsson et al., 1998). Knowing that EEDCs have such convoluted reaction possibilities, it is easier to detect the estrogenic potential of single chemicals or mixtures rather than exactly determine their mechanisms of actions, chemical interactions, and target tissues. Thus, detecting estrogenicity in water samples is an important assay in determining if fish have been exposed to EEDCs.

Accepted ways to biologically measure estrogen or EEDC exposure in fish include both in vivo and in vitro assays designed to detect the presence or induction of the vitellogenin gene. One of the most widely accepted in vitro methods is to use primary hepatocyte cultures from fish. The parenchymal liver cell, or hepatocyte, represents about $60-65 \%$ of the cells in the liver, but because of their size they occupy about $80 \%$ of the volume of the organ (Berry et al., 1991; Hampton et al., 1989). The isolation of liver cells was first described by Berry and Friend (1969). Hepatocytes 
are ideal metabolic systems because they retain in vitro many of their differentiated in vivo characteristics (Pessonen and Andersson, 1997). Primary cultured fish hepatocytes were first isolated by Klaunig et al., (1985) and were first used to measure vitellogenin induction by Maitre et al. (1986). Vitellogenin induction has been seen in hepatocyte mRNA at concentrations as low as $10^{-9} \mathrm{M}$ (Valliant et al., 1988).

Quantitative polymerase chain reaction (qPCR), also known as real-time PCR, is a highly sensitive in vitro method of detecting the induction of genes rather than a final protein product of the gene that has been induced (Bustin, 2000). Total ribonucleic acid (RNA) is extracted from cells or tissues and reverse transcriptase PCR is used to convert the RNA into circular deoxyribonucleic acid (cDNA). The primers anneal to the cDNA, or the complementary sequence of DNA, specific to the gene to be detected, and the primers allow for that sequence of DNA to be extended and amplified. When genes are amplified in qPCR there are two distinct methods for detecting this: the first being that primers tagged with a fluorophore will fluoresce when incorporated with its complementary strand of DNA and the second being that a dye included in the reaction will non-specifically intercalate with any double stranded DNA. In both methods, the amount of fluorescence directly correlates with the abundance of the specific genes being detected (Orlando et al., 1998). Once the fluorescence reaches a certain threshold, the thermocycler detects this and the increase in DNA product is used to determine the cycle threshold $\left(\mathrm{C}_{\mathrm{T}}\right)$. Since PCR is typically run for 40 cycles, any $\mathrm{C}_{\mathrm{T}}$ above 35 is generally considered non-specific binding of primers and product that shows up at this threshold is not used in analysis 
(Rasmussen et al., 1998). The technique measures a "house-keeping" gene, such as 18s, and target genes, such as vitellogenin. House-keeping genes are used as an internal standard because these genes are constitutively expressed over the life of the cell and are unaffected by any experimental conditions (Thellin et al., 1999). For example, 18s, a common house-keeping gene, is the small ribosomal subunit in a cell responsible for combining with the $28 \mathrm{~s}$ subunit in order to translate mRNA into proteins. It is abundant and present in all eukaryotic cells. The target gene is the gene of interest in the experiment. Since vitellogenin is a common biomarker for estrogen exposure, it is an appropriate target gene for detecting and measuring the relative estrogenicity of chemicals or chemical mixtures (Cheek et al., 2001; Sumpter and Jobling, 1995).

Rainbow trout is an established, commonly used species for hepatocyte isolation for estrogen screening because they are easy to maintain in tanks, and the isolation of hepatocytes is simple and straightforward. However, rainbow trout have not yet been seen in the fish kills reported in West Virginia and Virginia, while smallmouth bass (Micropterus dolomieu) have been found in these fish kills. Smallmouth bass are also identified as having intersex: as much as $100 \%$ at some sites along the South Branch Potomac, Shenandoah, and out-of-basin sites (V. Blazer et al., 2007). It follows that smallmouth bass should be investigated as potential sources for hepatocyte culture, because they are affected with intersex and seen in fish kills in this area.

The polar organic chemical integrative sampler (POCIS) is a common passive sampler for the detection of estrogenic compounds in rivers (Alvarez et al., 2004). It 
was first patented in 2002 by the United States Geological Survey (USGS). The sampler is deployed in a light-deprived area with a steady flow of water where it can remain completely submerged. POCIS is used to collect samples of water-soluble (polar or hydrophilic) organic chemicals. The sampler is set up to mimic the respiratory exposure of aquatic organisms, using a chamber between two porous membranes which traps the chemicals. By deploying the sampler and leaving it for a predetermined number of days, the time-weighted average concentrations of compounds can be calculated. The main benefit of this sampling technique is that it mimics the organisms without having to take into account any additional stressors, such as predator presence or spawning, which could alter the reliability of biomonitoring practices. Additionally, it allows for the detection of trace amounts of contaminants because it can be deployed for long periods of time mimicking bioaccumulation, which would be difficult with grab sampling. Wastewater treatment plants (WWTPs) are especially suspect in their contribution to EEDC contamination because they are unable to remove EEDCs from the treated water, thereby releasing these chemicals in their effluent. The expense involved in using activated charcoal filtration, which still would not be able to completely resolve the release of EEDCs, is cost-prohibitive. Estrogens and xenoestrogens have been detected in WWTP effluent from various countries across the world at environmentally relevant concentrations (Belfroid et al., 1999; Desbrow et al., 1998; Ternes et al., 1999).

A quick, easy and inexpensive method to perform a preliminary screen for estrogenicity is to use an estrogen-inducible bioluminescent yeast assay (BLYES). A strain of Saccharomyces cerevisiae was inserted with estrogen response elements and 
a luciferase gene, so that when the yeast is exposed to estrogen or EEDCs it fluoresces and can be read on a fluorescent plate reader (Sanseverino et al., 2005). Alvarez et al. (2009) used the BLYES assay to detect estrogenicity in the POCIS samples (Table 1) used in this study.

The specific objectives of this proposal were: 1) determination of the viability and quality of isolated smallmouth bass hepatocytes using established rainbow trout hepatocyte isolation techniques and selecting a medium in which to culture smallmouth bass hepatocytes for in vitro estrogen screening (Morphology and Viability experiment), 2) validating the use of smallmouth bass hepatocytes for in vitro estrogen screening and comparing their differential sensitivities to rainbow trout hepatocytes with known physiological concentrations of estrogen (Kinetics experiment), and 3) measurement of the level of estrogenicity of polar organic chemical integrative sampler extracts from sites on the Conococheague Creek and Monocacy River in Maryland, in Blue Plains, Washington, D.C., and at Leetown Science Center in Kearneysville, West Virginia (POCIS experiment), using vitellogenin induction as an endpoint.

\section{Materials and Methods}

\section{POCIS deployment sites and extractions}

POCIS deployment, extractions and analysis were all completed by Alvarez et al. (2009). For this experiment, POCIS were deployed in Conococheague Creek in Maryland, just upstream (in 2005, 2006) and downstream (in 2005, 2006) of the Conococheague Wastewater Treatment Plant (WWTP), in the Monocacy River in Maryland, just upstream (in 2005) and downstream (in 2005, 2006) of the Frederick 
WWTP, in Blue Plains, Washington D.C. (in 2005, a control), and in one of the closed ponds at USGS Leetown Science Center National Fish Health Research Laboratory (NFHRL) in Kearneysville, West Virginia (in 2006, a control; Fig. 1). The sites were selected based on their proximity to WWTP effluent. In 2005, the first set of POCIS were deployed for 31 days during the months of September and October and in 2006, a second set of POCIS were deployed for 49 days during April and May. The downstream sites were located immediately downstream of the WWTP discharges. Conococheague Creek is a $911 \mathrm{~km}^{2}$ watershed and has land use that is agricultural (61\%) and forested (34\%), with minor urban influence (5\%). The Monocacy River has a drainage area of $1,927 \mathrm{~km}^{2}$ and the land use of the Monocacy watershed is similar to the Conococheague watershed in that it is $60 \%$ agricultural, $33 \%$ forested, and $7 \%$ urban. In Washington, DC, the Blue Plains WWTP is the largest plant in the Potomac River watershed. The NFHRL reference site was a research pond with no WWTP input. This pond does receive surface water from other research ponds at the facility and therefore may be susceptible to chemical input from surface runoff and transport from nearby farms.

Extractions from the POCIS membranes were performed by Alvarez et al., (2009) using $50 \mathrm{ml}$ of 1:1:8 (v/v/v) methanol:toluene:dichloromethane, followed by $20 \mathrm{ml}$ of ethyl acetate. The extracts were evaporated, filtered, and combined into equal volume samples. Each class of chemical was separated from the entire extract volume. Organic wastewater chemicals were analyzed and identified by Agilent 6890 gas chromatograph (GC; Agilent Technologies, Santa Clara, CA) coupled to a 5973N mass-selective detector (MSD; Agilent Technologies, Santa Clara, CA). Agricultural 
pesticides were fractionated by size exclusion chromatography (SEC) and identified also using the previously described GC-MSD. For hormone analysis, the extracts were fractionated by SEC, fractionated again by adsorption chromatography, and then half of the sample was analyzed using a Hewlett-Packard 1090 Series II liquid chromatograph with a diode-array detector via high performance liquid chromatography (Agilent Technologies, Santa Clara, CA) and the other half was analyzed by the previously described GC-MSD.

Fish handling and storage

Smallmouth bass $(150-600 \mathrm{~mm})$ were held in the closed ponds at the USGS Leetown Science Center NFHRL in Kearneysville, WV and were fed minnows from a stocked minnow pond. The bass came from the South Branch of the Potomac River and were kindly provided by Jim Hedrick of the West Virginia Department of Natural Resources. Female rainbow trout $(150-400 \mathrm{~mm})$ were held in green, circular 2000 liter tanks (15 $\pm 1 \mathrm{C})$ and photoperiod was maintained at $12 \mathrm{~h}: 12 \mathrm{~h}$, light:dark cycle. Male rainbow trout $(400-750 \mathrm{~mm})$ were held in green, circular 1500 liter tanks $(15 \pm 1 \mathrm{C})$. All rainbow trout were received from Jim Everson at the USDA National Center for Cool and Cold Water Aquaculture. Rainbow trout were fed $5 \mathrm{~mm}$ pelleted, nonfloating feed (Zeigler, Gardners, PA). Water quality parameters including dissolved oxygen, $\mathrm{pH}$, and temperature were measured prior to experiments in the event of fluctuations in these parameters and weekly throughout the experiment. The fish were fed daily and acclimatized to their surroundings for a minimum of 4 weeks prior to euthanasia as described below. 


\section{Fish hepatocyte isolation}

Hepatocytes were isolated from both rainbow trout and smallmouth bass for estrogen screening. Rainbow trout and smallmouth bass were euthanized using Finquel ${ }^{\circledR}$ tricaine methanesulfonate (MS-222), placed in a sterile hood, and sprayed with $70 \%$ isopropanol. The fish were opened aseptically and the liver removed to a sterile Petri dish. A 10cc syringe filled with a calcium-free phosphate buffered saline solution (CFPBS) (pH 7.4, $142 \mathrm{mM} \mathrm{NaCl}, 5.4 \mathrm{mM} \mathrm{KCl,} 0.42 \mathrm{mM} \mathrm{Na}_{2} \mathrm{HPO}_{4}, 0.44$ $\mathrm{mM} \mathrm{KH}_{2} \mathrm{PO}_{4}, 0.43 \mathrm{mM} \mathrm{NaHCO} 3,1 \mathrm{mM} \mathrm{L}$-glutamine), was used to flush the liver in order to remove red blood cells (RBCs). The liver was massaged with sterile forceps during the flush which facilitated the removal of RBCs. The liver was moved to a new sterile Petri dish for a 10 minute direct stick perfusion with Type 2 collagenase isolated from Clostridium histolyticum (Gibco, Carlsbad, CA) at 17,500 collagen digestion units (CDU)/20ml of CFPBS, and the liver was massaged after five minutes to ensure the collagenase moved through the liver adequately. When the liver started to break up, a sterile number 10 scalpel was used to dice it into small pieces. The solution was then pushed through a $3 \mathrm{cc}$ syringe to break up the liver even further and then the solution was allowed to digest in the collagenase for 10 more minutes and the solution was again flushed through the $3 \mathrm{cc}$ syringe. Digested liver was passed through 310um and 70um nylon mesh consecutively, using a calcium-containing phosphate buffered saline solution (CCPBS) (pH 7.4, $142 \mathrm{mM} \mathrm{NaCl}, 5.4 \mathrm{mM} \mathrm{KCl}$, $0.42 \mathrm{mM} \mathrm{Na}_{2} \mathrm{HPO}_{4}, 0.44 \mathrm{mM} \mathrm{KH}_{2} \mathrm{PO}_{4}, 0.43 \mathrm{mM} \mathrm{NaHCO}_{3}, 2.4 \mathrm{mM} \mathrm{CaCl}$ ), to wash the Petri dish and filters, while cells were gently pushed through the larger mesh with the syringe plunger. The solution was centrifuged at $50 \mathrm{~g}$ for 5 minutes at $4 \mathrm{C}$ and the 
cells were resuspended in three types of phenol-red free media: Williams' Medium E (Sigma-Aldrich, St. Louis, MO), Opti-Mem (Gibco, Carlsbad, CA), L-15 (Gibco, Carlsbad, CA). The cells were counted using a hemacytometer, and plated at $1 \times 10^{5}$ cells per well in clear flat-bottomed 96-well sterile tissue culture plates. Rainbow trout hepatocytes were cultured in air at $15 \mathrm{C}$, which was the temperature the fish were maintained at in their tanks, while smallmouth bass were cultured in air at $19 \mathrm{C}$, which was the temperature of the water the day they were collected from the South Branch of the Potomac River.

In vitro exposures

Cells were isolated as above and plated in clear flat-bottomed, 96-well sterile tissue culture plates. This was done twice: once for the kinetics assay for a three day period in trout and a seven day period for smallmouth bass, and once for the POCIS assay for three days in rainbow trout. For the kinetics assay, hepatocytes were exposed to $0 \mathrm{nM}, 1.2 \mathrm{nM}$, and $12 \mathrm{nM}$ of $\mathrm{E}_{2}$ that were included on each plate in triplicate. The plates were cultured in air at their respective temperatures over the days of the experiments. First, the kinetics assay was performed on rainbow trout hepatocytes to ensure the assay worked. At each 24 hour interval over the three day period, the supernatant was removed and the cell pellet harvested using 200ul RNAlater. Harvested cells were frozen at $-80^{\circ} \mathrm{C}$ until RNA extraction begins. For the POCIS assay, extracts from the POCIS water samplers were concentrated using a DNA110-120 SpeedVac Savant (Thermo Scientific, Waltham, MA) and resuspended in L-15 and 10ul of extract was added to the wells, to give a working concentration of $10 \%$, in triplicate, as well as $0 \mathrm{nM}$ and a second significant (low or high) 
concentration of $E_{2}$ determined above. The cells were kept in culture for 3 days for rainbow trout. At this time the plates were spun down at $300 \mathrm{~g}$ for 5 minutes, the supernatant removed and the cell pellet harvested using 200ul RNAlater. Again, harvested cells were frozen at $-80^{\circ} \mathrm{C}$ until RNA extraction began.

Total RNA extraction, cDNA synthesis, and qPCR

RNA was extracted to perform qPCR to measure $18 \mathrm{~s}$ and vitellogenin induction in the hepatocytes. Frozen cells stored in RNAlater were thawed on ice. Using Qiagen RNeasy Mini kit (Qiagen, Valencia, CA), the cells were centrifuged, the RNAlater supernatant was removed and the pellet were resuspended in 350ul of RLT buffer. Then 350ul of 70\% RNase/DNase-free ethanol was added to the cell solution. The entire solution (700ul) was pipetted onto an RNeasy spin column and centrifuged at $\geq 8,000 \mathrm{~g}$ for 15 seconds, and flow-through was discarded. A DNase digestion step was performed next. The first step was repeated using 700ul RW1 buffer pipetted onto the column. Two wash steps were performed using 500ul of RPE buffer pipetted onto the column and then centrifuged and discarded. Next 30ul of RNase/DNase-free water was added to elute the RNA off the column into an RNAse/DNase-free microcentrifuge tube, spinning the tube at $\geq 8,000 \mathrm{~g}$ for 1 minute. The total RNA was quantified using the NanoDrop NC-1000 (NanoDrop, Wilmington, DE). cDNA synthesis was performed using Applied Biosystems Reverse Transcription kit (Foster City, CA). To PCR tubes, master mix, prepared for the cDNA synthesis reaction as indicated in Table 2, was added to tubes, along with $625 \mathrm{ng}$ of RNA. The tubes were then brought up to $10 \mu \mathrm{L}$ total volume with nucleasefree water. Samples were centrifuged to the bottom, and placed in the Mastercycler 
thermocycler (Eppendorf, Westbury, NY): first step: $25 \mathrm{C}$ for 10 minutes; second step: $37 \mathrm{C}$ for 120 minutes; third step: $85 \mathrm{C}$ for 5 seconds and then $4 \mathrm{C}$ until the cycle was complete and then the samples were stored at $-20 \mathrm{C}$ until ready for qPCR. Applied Biosystems (Foster City, CA) SYBR Green Master mix for Real-time PCR was prepared as in Table 3. To a 384 well real-time PCR plate, $10 \mu \mathrm{L}$ of the master mix was added to the appropriate number of wells along with 1 ul of cDNA to each well. The plate was tapped on the lab bench to mix and remove bubbles and centrifuged briefly to collect the contents in the bottom of the well. Real-time PCR was performed on Applied Biosystems Incorporated 7900HT Fast Real-Time PCR system (Foster City, CA).

\section{Morphology and Viability experiment-Design and Set up}

Hepatocytes from two species of fish (smallmouth bass and rainbow trout, three of each regardless of sex) were isolated as above and plated into 96-well plates at $1 \times 10^{5}$ cells per well to determine hepatocyte morphology and viability. Rows on the plates were filled per fish species, and each plate represented a successive 24 hour exposure. Clear sterile tissue culture plates were used for the media comparison experiment. In this experiment, three types of media were tested to assess which media should be used to culture the isolated hepatocytes in the second and third experiments. On each day of the exposure for seven days, the cells were imaged using a Canon EOS Digital Rebel T1i EF-S digital camera (Canon, Lake Success, NY) and then treated with 3-(4,5-Dimethylthiazol-2-yl)-2,5-diphenyltetrazolium bromide (MTT) (Sigma-Aldrich, St. Louis, Mo) to assess cell viability. The medium in which both types of fish cells were viable, morphologically sound, and adhere to the plates 
was used for the second and third experiments. For morphology and viability, the optimal medium to culture the cells was determined by comparing phenol red-free Williams' Medium E (5\% charcoal stripped FBS, 2mM L-glutamine, 1 X pen-strep, 50mM HEPES), phenol red-free Opti-MEM (5\% charcoal stripped FBS, $1 \mathrm{X}$ penstrep) and phenol red-free L-15 (5\% charcoal stripped FBS, 1X pen-strep). The plated cells were exposed to media only as the positive control and Triton X-100 as the negative control ( $\mathrm{n}=4$ per treatment per medium). Exposures occurred over 7 days. To observe morphology, digital pictures were taken of the cells in the plate to record any changes such as clumping, shrinking, and loss of adherence and then for each time point, the plate was assessed for viability using MTT, which measured mitochondrial reductase activity. Ten microliters of 5\% stock MTT in the respective media was added to each well. Cells were replaced in their respective incubators for 2 hours. The cells with normal cellular activity converted the MTT to its salt form, forming purple crystals. After two hours, acid isopropanol was added, dissolving the purple crystals, if formed, and the plate was read on a SpectraMax 250 Microplate Reader at $570 \mathrm{~nm}$ and 620nm (background) (Molecular Devices, Winooski, VT). Dark purple coloration (high optical density [OD] readings) indicates cells that are performing normal mitochondrial reductase activity and are therefore content in their environment. Light purple or yellow coloration (low OD readings) indicates cells are not performing normal enzymatic activity.

\section{Kinetics experiment-Design and Set up}

For the kinetics experiment using 17- $\beta$ estradiol $\left(\mathrm{E}_{2}\right)$ experiment, hepatocytes from six males and six females of both smallmouth bass and rainbow trout were 
isolated as above and plated (in clear 96-well plates; per row, one male or female of each species). Within this experiment, each row of cells was exposed to a media only control, a vehicle control, and $0 \mathrm{nM}, 1.2 \mathrm{nM}$, and $12 \mathrm{nM}$ of $17-\beta$ estradiol, in duplicate. After exposure, RNA was extracted from each sample, cDNA was synthesized and qPCR was performed for the $18 \mathrm{~s}$ gene and the vitellogenin gene respective to each species.

POCIS experiment-Design and Set up

For the POCIS experiment, hepatocytes from six male and six female rainbow trout were isolated and plated (in clear 96-well plates, per row, one male or female) and then were exposed to a media only control and $12 \mathrm{nM}$ of $17-\beta$ estradiol, in duplicate and $10 \%$ concentrations of each water sampler extract (from sites and years listed in Table 1), in duplicate. After 3 days exposure, RNA was extracted, cDNA was synthesized and the samples were analyzed for the $18 \mathrm{~s}$ gene and the vitellogenin gene using qPCR.

\section{Statistics}

Statistical analysis was performed using Microsoft Office Excel 2003 (Microsoft Corporation, Redmond, WA) and R: A Language and Environment for Statistical Computing 2009 (R Foundation for Statistical Computing, Vienna, Austria). For viability data, average sample OD readings were reported in reference to control OD readings as a percentage increase.

All qPCR data collected was normalized relative to the house-keeping gene 18s. The $\mathrm{C}_{\text {Ttarget }}$ and $\mathrm{C}_{\text {Treference }}$ were each averaged and then the ratio calculated to yield the mean normalized gene expression. The average normalized data of the 
kinetics assay was reported as is. The normalized expression data of female trout exposed to POCIS water extracts were statistically evaluated using a Kruskal-Wallis nonparametric test $(\alpha=0.01)$ to measure relative abundance of vitellogenin.

\section{Results}

Morphology and Viability experiment

Overall, L-15, Opti-MEM, and William's Medium E were studied with regard to their ability to support rainbow trout and smallmouth bass hepatocytes for up to seven days in culture. Cell morphology and viability was judged based on microscopic examinations and the MTT viability assay, respectively. Results from this experiment show that viability readings for the rainbow trout positive control on day one through day five in L-15 were on average $70 \%$ higher than the media only blank. For the negative control, readings were on average $1 \%$ higher than the media only blank. Readings for the rainbow trout positive control in Opti-MEM were on average $62 \%$ higher than the media only blank and the negative control readings were, on average, $0 \%$ higher than the media only blank. Readings for the rainbow trout positive control in William's Medium E were, on average, 59\% higher than the media only blank and the negative control readings were $0 \%$ higher than the media only blank. After day five, viability readings decreased by two-fold indicating a reduction in cell number.

Readings for the smallmouth bass positive control on day one through day 5 in L-15 were on average $36 \%$ higher than the media only blank. For the negative control, readings were on average $2 \%$ higher than the media only blank. Readings for the smallmouth bass positive control in Opti-MEM were on average $28 \%$ higher than 
the media only blank and the negative control readings were, on average, $0 \%$ higher than the media only blank. Readings for the smallmouth bass positive control in William's Medium E were, on average, $27 \%$ higher than the media only blank and the negative control readings were $0 \%$ higher than the media only blank.

Morphologically, there were no distinct differences in the cultures of cells between the different media. Digital pictures were taken and the cultures were visually assessed (Figs. 2 and 3). Aggregates were formed identically and adherence decreased until day five. On days five, six and seven in the smallmouth bass culture, the cells were free floating and viability readings decreased. From the results of this experiment, L-15 supported both the rainbow trout and smallmouth bass hepatocyte isolations, and was chosen as the medium in which to culture the hepatocytes in the kinetics and POCIS experiments.

\section{Kinetics experiment}

For the kinetics experiment, rainbow trout and smallmouth bass hepatocytes were exposed to two concentrations of $17-\beta$ estradiol, a media only negative control, and a vehicle negative control (methanol). In rainbow trout males and females, the house-keeping gene $18 \mathrm{~s}$ showed no significant alterations in mRNA expression levels between experimental groups. The $18 \mathrm{~s}$ gene was not affected by the duration time of culturing (3 days). The range in threshold cycle $\left(\mathrm{C}_{\mathrm{T}}\right)$ values, from $21-34$ cycles, is most likely attributable to the variations of individual fish or the efficiency of cDNA synthesis and qPCRs. There were no differences in the threshold cycle values between the media only negative control and the vehicle only negative control, 
therefore, the use of methanol as a vehicle had no adverse affect on the cells while in culture.

In both smallmouth bass males and females, $18 \mathrm{~s}$ was not detected in cultures from days one through five in samples from cells either exposed to $17 \beta$-estradiol or both negative controls. The media only negative controls did not differ from the vehicle only negative controls or the $17 \beta$-estradiol exposed cells at any significant level.

In male and female rainbow trout, vitellogenin, the target gene, was detected on days 2 and 3, with day three being the peak induction day. In the absence of exposure to $17 \beta$-estradiol, for rainbow trout males there were no differences in the threshold cycle values between the negative controls in vitellogenin induction. The abundance of mRNA was found to be below the level of detection of the qPCR system. In the absence of exposure to $17 \beta$-estradiol, rainbow trout female vitellogenin mRNA was found to be at or slightly above the level of qPCR detection. At high concentrations of $17 \beta$-estradiol $(12 \mathrm{nM})$, rainbow trout males had a 4.5-fold increase in vitellogenin induction over the negative controls. The low concentration $(1.2 \mathrm{nM})$ did not cause an increase, so that the vitellogenin levels were just below the level of detection. At high concentrations, the slight range in threshold values $\left(\mathrm{C}_{\mathrm{T}}=27-32\right.$ cycles $)$ is likely due to individual fish or the efficiency of cDNA synthesis and qPCRs. In rainbow trout females, high concentrations of $17 \beta$-estradiol induced vitellogenin at levels at a 32-fold increase over the negative controls and at low concentrations vitellogenin was induced at a 12 -fold increase over negative controls. For rainbow trout females at both concentrations, the slight range in 
threshold values (19-23 cycles) is likely due to individual fish or the efficiency of cDNA synthesis and qPCRs.

In the absence of $17 \beta$-estradiol exposure, smallmouth bass males and females had no increase in vitellogenin induction over the negative controls. At high concentrations $(12 \mathrm{nM})$ of $17 \beta$-estradiol exposure, smallmouth bass males and females had no significant differences in vitellogenin induction over negative controls. Vitellogenin induction was not significantly different from negative controls in male and female smallmouth bass at low concentrations of $17 \beta$-estradiol (1.2nM).

\section{POCIS experiment}

For this experiment, male and female rainbow trout hepatocytes were exposed to a media only control, a $17-\beta$ estradiol control $(12 \mathrm{nM})$, and $10 \%$ total concentration of each sample (Table 1). In rainbow trout males and females, 18s, the house-keeping gene, showed no significant alterations in mRNA expression levels between the different exposures, and it was not affected by the culture time of 3 days. The range in threshold cycle values, from 21-34 cycles, is likely attributed to the variations of individual fish or the efficiency of cDNA synthesis and qPCRs.

Vitellogenin was not induced in male rainbow trout at any level when exposed to samples (Table 1), however, vitellogenin was induced when exposed to the $\mathrm{E}_{2}$ positive control but at very low levels $\left(\mathrm{C}_{\mathrm{T}}=37.8\right)$. In female rainbow trout, vitellogenin was induced at low levels in the following samples: POCIS control 2005 $\left(\mathrm{C}_{\mathrm{T}}=37.8\right)$, Upper Conococheague field blank $\left(\mathrm{C}_{\mathrm{T}}=36.7\right)$, Upper Conococheague POCIS $2005\left(C_{T}=36.7\right)$, Upper Monocacy POCIS $2006\left(C_{T}=34.8\right)$, and the Lower Conococheague field blank $2006\left(\mathrm{C}_{\mathrm{T}}=37\right)$. However, the $\mathrm{C}_{\mathrm{T}}$ for all positive samples 
was at or above 35, indicating non-specific product amplification. The samples from Table 1 were previously screened for estrogenicity using BLYES and all of the samples were shown to have estrogenicity. Known estrogenic compounds were found to be present in the samples by Alvarez et al. (2009), as indicated by chemical analysis (Table 4). Normalized data from 2005 were compared and no statistically significant differences were seen from the Kruskal-Wallis nonparametric test $(p=0.1$; Fig. 4). Normalized data from 2006 were compared and no statistically significant differences were seen from the Kruskal-Wallis non parametric test ( $p=0.03$; Fig. 5). In addition the $\mathrm{C}_{\mathrm{T}}$ indicates that $\mathrm{qPCR}$ did not show biologically significant vitellogenin induction. Smallmouth bass were not included in this experiment because of the inability to obtain qPCR data from the kinetics experiment in reference to the house-keeping gene $18 \mathrm{~s}$ and the target gene vitellogenin.

\section{Discussion}

\section{Morphology and Viability Experiment}

Rainbow trout hepatocytes were successfully cultured in the morphology and viability experiment (Fig. 3). The average viability indicated mitochondrial reductase activity, as seen by higher OD readings. The mitochondrial reductase activity did decrease over time and decreased differently depending on which media was used to culture the cells. Cells cultured in L-15 had the highest average viability so it follows that it was an appropriate media to culture the cells for the kinetics and POCIS assays. Other laboratories have also used L-15 to successfully culture rainbow trout hepatocytes (Kim and Takemura, 2003; Klaunig et al., 1985; Tollefsen et al., 2003; Schreer, 2005). 
The initial isolations of smallmouth bass yielded large cell counts in all three media, with L-15 allowing for the largest amount of viable cells recovered. Previous work at the University of Florida attempted to isolate smallmouth bass hepatocytes specifically for in vitro estrogenicity screening; however their isolation was unsuccessful (C. Bowman, personal communication). Although we did isolate smallmouth bass hepatocytes using an established teleost hepatocyte technique in this study, the cells had reduced viability compared to rainbow trout according to the MTT assay. The cells did not adhere and establish a monolayer of cells within a few days of culture as shown by the digital pictures (Fig. 2). These results were surprising as the isolation looked promising.

L-15 supported smallmouth bass hepatocytes the best out of the three media we selected for our study however cellular adherence, cell viability, and cellular resilience were not as expected. Klaunig et al. (1985) showed that primary cell cultures of hepatocytes from fish are viable no more than 7 days in culture. Problems in retrieving functionally viable cells could be caused by an alteration from the ideal media composition, which has been linked to changes in cellular ion balance (Moor et al., 2000), decreased cell growth rate (Zhou et al., 1997), reduced cellular metabolism (Takagi et al., 2000), activation or deactivation of cellular signaling (Lezama et al., 2005 ) and alterations in cellular gene expression (Wu et al., 2004). Hepatocyte adherence can be enhanced by prior coating of the culture plates with an extracellular matrix (ECM) but is not required (Maitre et al., 1986). Coating has been shown to be successful using different types of matrices such as collagen (Kocal et al., 1988), fibronectin (Hayashi and Ooshiro, 1985), and fish skin extract (Blair et al., 1990) in 
conjunctions with using media supplemented with fish serum, but not fetal bovine serum. We suggest matrix technology and more specific culturing parameters to be implemented in future attempts to isolate smallmouth bass hepatocytes.

\section{Kinetics Experiment}

Rainbow trout male and female hepatocytes were successfully used in the kinetics assay. The female rainbow trout hepatocytes exposed to $17-\beta$ estradiol showed induction levels of vitellogenin similar to values previously reported by Schreer et al. (2005). Although vitellogenin was only induced during exposure to the high concentration of $17-\beta$ estradiol in male fish, it has been seen in other laboratory settings. Okoumassoun et al. (2002) exposed hepatocytes from male rainbow trout to $17-\beta$ estradiol and found vitellogenin induction at exposure levels as low as $0.1 \mathrm{nM}$. Marlatt et al. (2006) showed a distinct increase in vitellogenin production over increasing concentrations $(0.1 \mathrm{nM}$ to $1000 \mathrm{nM})$ of exposure to 17 - $\beta$ estradiol.

From the RNA extractions of the isolated smallmouth bass hepatocytes, we saw very low yields of RNA, which has also been seen by other laboratories conducting similar experiments (L. Robertson, personal communication). The extracted RNA, as little as $4 \mathrm{ng} / 40 \mu \mathrm{L}$ sample, either did not yield cDNA or did not yield enough to use as a template in qPCR so that neither the $18 \mathrm{~s}$ nor the vitellogenin gene could be amplified to detectable levels. Primers are sensitive to the annealing temperature during qPCR, and this is why primer optimization is an important step in designing primers. Annealing temperature is one of the most important parameters in qPCR, so to check that the qPCR protocol was correct we tried 3 different annealing temperatures $\left(55^{\circ} \mathrm{C}, 58^{\circ} \mathrm{C}\right.$, and $\left.60{ }^{\circ} \mathrm{C}\right)$, however we still saw no smallmouth bass $18 \mathrm{~s}$ 
or vitellogenin being amplified. To date, other laboratories have used enzyme-linked immunosorbent assays (ELISA) to measure vitellogenin levels in the plasma of smallmouth bass (Anderson et al., 2008; Guevel and Pakdel, 2001). Other methods to detect vitellogenin in smallmouth bass used extracted RNA from hepatocyte aggregates to perform dot blots to detect radio-labeled vitellogenin (Guevel and Pakdel, 2001) and qPCR performed on homogenized whole liver samples (Biales et al., 2007).

\section{POCIS Experiment}

The results of the POCIS study conducted with female rainbow trout indicate that there were no statistically significant differences in estrogenic activity of POCIS collected in 2005 and 2006. In both sampling years, the samples that showed induction all had lower levels of induction or only slightly higher levels than the negative controls, therefore, background subtraction would put the sample induction levels at or near zero. Additionally, looking at the cycle threshold reported in the results for both years, amplification that shows up above $\mathrm{C}_{\mathrm{T}}=35$ is generally considered non-specific amplification, so we could not with absolute certainty attribute the values specifically to vitellogenin induction. These factors indicate that the vitellogenin induction measured by qPCR in the female rainbow trout hepatocytes was not significant. Male rainbow trout hepatocytes indicated no induction of vitellogenin upon exposure to the extracts. Although we saw no vitellogenin induction, male hepatocytes are known to produce vitellogenin when exposed to WWTP effluent as seen by Purdom et al. (1994). 
Overall results of this study indicate that using qPCR to detect induction of vitellogenin in primary cell culture hepatocytes is not the best or most sensitive method for the low concentrations of the chemicals found in our POCIS extracts (Table 4). Detection methods of vitellogenin in primary cell cultures of fish hepatocytes currently include ELISAs (Rankouhi et al., 2002, Okoumassoun et al., 2003)), slot blot analysis (Fluoriet et al., 1993) and radioimmunoassays (Fluoriet et al., 1993). Quantitative PCR is typically used in in vivo studies rather than in vitro (Biales et al., 2007; Hogan et al., 2008), and stimulation of whole fish with $E_{2}$ was found to induce vitellogenin protein production up to 1000 -fold higher than the vitellogenin mRNA transcript (Thomas-Jones et al., 2003). Fluoriet et al. (1993) found that rainbow trout hepatocytes in monolayer did produce vitellogenin mRNA from days 1-8 as measured by slot blot analysis. Huggett et al. (2003) found that the BLYES assay severely underestimated the estrogenic potential of WWTP effluent when compared to in vivo exposures of male Japanese medaka (Oryzias latipes). Rutishauser et al. (2004) also found the BLYES assay to be 2 to 3 -fold less sensitive than hepatocyte in vitro methods. Male fish primary hepatocytes have repeatedly been used successfully for the detection of estrogenicity of wastewater effluent (Anderson et al., 1996; Gagne and Blaise, 1998; Jobling and Sumpter, 1993; Pelissero et al., 1993; Segner et al., 2003). Surfactants found in wastewater effluent have also been found to be weakly estrogenic to fish (Jobling and Sumpter, 1993). Although significant differences in vitellogenin induction have been seen in rainbow trout hepatocytes upon exposure to water samples from upstream and downstream of 
wastewater treatment plants, qPCR is not used often to measure in vitro vitellogenin induction.

\section{Future Considerations}

First and foremost, we suggest exploring options for optimizing the culturing technique for smallmouth bass hepatocyte. Isolation and culture of hepatocytes is very specific and each step should be optimized for the individual species of fish. We think that two of the main components that reduced smallmouth bass hepatocyte viability were growth medium composition and cellular adherence. There are many factors that lend to the optimization of a culture medium, such as amino acid supplementation, ideal serum concentration and type, osmolality, buffering agents, and the addition of other growth factors, not to mention the base medium itself. Also, cellular adherence is of primary importance when cells are trying to create a monolayer in vitro. Smallmouth bass hepatocytes may be more inclined to attach and grow in the presence of an ECM as well as supplementing the incubation media with charcoal-stripped smallmouth bass serum rather than charcoal-stripped fetal bovine serum. Further research into the optimum medium composition for smallmouth bass hepatocytes would help to create ideal culturing conditions allowing for the use of these hepatocytes for in vitro experiments.

Our second recommendation is to use fish within previously determined size and age limits that have successfully shown vitellogenin induction after exposure to wastewater effluent. Typically, juvenile males and females are used. This indicates that during critical developmental windows, younger fish are more sensitive to 
estrogenic compounds found in wastewater effluent and vitellogenin can be induced more easily.

A third possibility is if the isolation technique is optimized to yield more viable smallmouth bass hepatocytes but still yielded low RNA levels, one remedy could be the amplification of the RNA itself prior to cDNA synthesis. It is believed (and becoming a common practice) that this is a proper method for successful cDNA synthesis, thereby giving a template for successful qPCR. 


\section{Literature Cited}

Arcand-Hoy, L.D., A.C. Nimrod, and W. H. Benson. 1998. Endocrine-modulating substances in the environment: estrogenic effects of pharmaceutical products. International Journal of Toxicology 17:139-158.

Alvarez, D.A., J.D. Petty, J.N. Huckins, T.L. Jones-Lepp, D.T. Getting, J.P. Goddard, and S.E. Manahan. 2004. Development of a passive, in situ, integrative sampler for hydrophilic organic contaminants in aquatic environments. Environmental Toxicology and Chemistry 23:1640-1648.

Alvarez, D.A., W.L. Cranor, S.D. Perkins, V.L. Schroeder, L.R. Iwanowicz, R.C. Clark, C.P Guy, A.E. Pinkney, V.S. Blazer and J.E. Mullican. 2009. Reproductive health of bass in the Potomac, USA, Drainage: Part 2. Seasonal Occurrence of Persistent and emerging organic contaminants. Environmental Toxicology and Chemistry 28:1084-1095.

Anderson, D.P. 1996. Environmental factors in fish health: Immunologic responses. Fish Physiology 15:289-310.

Anderson, M.J., D. Cacela, D. Beltman, S. J. Teh, M. S. Okihiro, and D. E. Hinton. 2008. Biochemical and toxicopathic biomarkers assessed in smallmouth bass recovered from a polychlorinated biphenyl-contaminated river. Environment International 34: 531-545

Anglade, I., F. Pakdel, T. Bailhache, F. Petit, G. Salbert, P. Jego, Y. Valotaire, and O. Kah. 1994. Distribution of estrogen receptor-immunoreactive cells in the brain of the rainbow trout (Oncorhynchus mykiss). Journal of Neuroendocrinology 6:573-583.

Belfroid, A., A. Van der Horst, A.D. Vethaak, A.J. Schäfer, G.B.J. Rijs, J. Wegener, and W.P. Confino.1999. Analysis and occurrence of estrogenic hormones and their glucuronides in surface water and waste water in The Netherlands. Science of the Total Environment 225:101-108.

Berry, M.N., and D.J. Friend. 1969. High-yield preparation of isolated rat liver parenchymal cells. Journal of Cellular Biology 43:506-520.

Berry, M.N., A.M. Edwards, and G.J. Barritt. 1991. Isolated hepatocytes: preparation, properties, and application. Elsevier Scientific Publishing, Amsterdam, The Netherlands.

Biales, A.D., D.C. Bencic, J.L. Lazorchak, and D.L. Lattier. 2007. A quantitative real-time polymerase chain reaction method for the analysis of vitellogenin transcripts in model and nonmodel species. Environmental Toxicology and Chemistry 26:2679-2686. 
Bishop C.A., R.J. Brooks, J.H. Carey, P. Ng, R.J. Norstrom, D.R.S.J. Lean.1991. The case for a cause-effect linkage between environmental contamination and development in eggs of the common snapping turtle (Chelydra s. serpentina) from Ontario, Canada. Journal of Toxicology and Environmental Health 33:521-548.

Blair, J.B., M.R. Miller, D. Pack, R. Barnes, S.J. Teh, and D.E. Hinton. 1990. Isolated trout liver cells: establishing short-term primary cultures exhibiting cell-to-cell interactions. In Vitro Cellular and Developmental Biology 26:237-249.

Blazer, V.S., L.R. Iwanowicz, D.D. Iwanowicz, D.R. Smith, J.A. Young, J.D. Hedrick, S.W. Foster, and S.J. Reeser. 2007. Intersex (testicular oocytes) in smallmouth bass from the Potomac River and selected nearby drainages. Journal of Aquatic Animal Health 19:242-253.

Bustin, S.A. 2000. Absolute quantification of mRNA using real-time reverse transcription polymerase chain reaction assays. Journal of Molecular Endocrinology 25:69-193.

Cheek, A., T.H. Brouwer, S. Carroll, S. Manning, J. McLachlan, and M. Brouwer. 2001. Experimental evaluation of vitellogenin as a predictive biomarker of reproductive disruption. Environmental Health Perspectives 109:681-690.

Davis, W.P., and S.A.Bortone. 1992. Effects of kraft mill effluent on the sexuality of fishes: an environmental early warning? Pages 113-127 in T. Colborn and C. Clement, editors.Chemically induced alterations in sexual and functional development: the wildlife/human connection. Princeton Scientific Publishing, Princeton, NJ, U.S.A.

Desbrow, C., E. J. Rutledge, G.C. Brighty, J.P. Sumpter, and M. Waldock. 1998. Identification of estrogenic chemicals in STW effluent: 1. Chemical fractionation and in vitro biological screening. Environmental Science and Technology 32:1549-1558.

Dunier, M., and A. K. Sawicki. 1993. Effects of pesticides and other organic pollutants in the aquatic environment on the immunity of fish: a review. Fish and Shellfish Immunology 3:423-438.

Ellis, D.V., and L.A. Pattisina. 1990. Widespread neogastropod imposex: a biological indicator of global TBT contamination. Marine Pollution Bulletin 21:248-253.

Erdman, T.C. 1998. Report to U.S. Fish and Wildlife Service on common and Forster's tern productivity on Kidney Island confined disposal facility, Green Bay, 1987 with supplemental necropsy and pathology reports. Green Bay, University of Wisconsin. 
Fluoriot, G., C. Valliant, C. Salbert, G. Pelissero, J.M. Guiraud, and Y. Valotaire. 1993. Monolayer and aggregate cultures of rainbow trout hepatocytes: Longterm and stable liver-specific expression in aggregates. Journal of Cell Science 105:407-416.

Fry, D.M., and C.K. Toone. 1981. DDT-induced feminization of gull embryos. Science 231:919-924

Gagné, F., and C. Blaise. 1998. Differences in the measurement of cytotoxicity of complex mixtures with rainbow trout hepatocytes and fibroblasts.

Chemosphere 37:753-69.

Gibbs, P.E., P.L. Pascoe, and G.R. Burt. 1988. Sex change in the female dog-whelk (Nucella lapillus) induced by tributyltin from antifouling paints. Journal of Marine Biology Association, UK 68:715-731.

Hampton, J.A., R.C. Lantz and D.E. Hinton. 1989. Functional units in rainbow trout (Salmo gairdneri, Richardson) liver. III. Morphometric analysis of parenchyma, stroma, and component cell types. American Journal of Anatomy 185:58-73.

Hayashi, S., and Z. Ooshiro. 1985. Primary culture of the freshly isolated liver cells of the eel. Bulletin of the Japanese Society for the Science of Fish 51:765-771.

Hogan, N.S., C. A.Wartman, M.A. Finley, J. G. van der Lee, and M. R. van den Heuvel. 2008. Simultaneous determination of androgenic and estrogenic endpoints in the threespine stickleback (Gasterosteus aculeatus) using quantitative RT-PCR. Aquatic Toxicology 90:269-276.

Huggett, D.B., C.M. Foran, B.W. Brooks, J. Weston, B. Peterson, K.E. Marsh, T.W. La Point, and D. Schlenk. 2003. Comparison of in Vitro and in Vivo Bioassays for Estrogenicity in Effluent from North American Municipal Wastewater Facilities. Toxicological Sciences 72:77-83.

Jobling, M. 1995. Reproduction. Pages 297-355 in M. Jobling, editor. Environmental Biology of Fishes. Chapman and Hall, London, England.

Jobling, S., and J.P. Sumpter. 1993. Detergent components in sewage effluent are weakly oestrogenic to fish: and in vitro study using rainbow trout (Oncorhynchus mykiss) hepatocytes. Aquatic Toxicology 27:361-372.

Jobling, S., and C.R. Tyler. 2003. Endocrine disruption, parasites and pollutants in wild freshwater fish. Parasitology 126:S103-S108. 
Kim, B.H. and A. Takemura. 2003. Culture conditions affect induction of vitellogenin synthesis by estradiol-17 beta in primary cultures of tilapia hepatocytes. Comparative Biochemistry and Physiology: Part B 135:231-239.

Klaunig, J.E., R.J. Ruch, and P.J. Goldblatt. 1985. Trout hepatocyte culture: isolation and primary culture. In Vitro Cellular and Developmental Biology 21:221228.

Kocal, T., T.L. Crane, B.A. Quinn, H.W. Ferguson, and M.A. Hayes. 1988. Degradation of extracellular thymidine by cultured hepatocytes from rainbow trout (Salmo gairdneri). Comparative Biochemistry and Physiology: Part B 91:557-561.

Kubiak, T.J., H.J. Harris, L.M. Smith, T.P. Schwartz, D.L. Stalling, J.A. Trick, L. Sileo, D.E. Docherty, and T.C. Erdman. 1989. Microcontaminants and reproductive impairment of the Forster's tern on Green Bay, Lake Michigan1983. Archives of Environmental and Contaminant Toxicology 18:706-727.

Larsson, D.G. J., M. Adolfsson-Erici, J. Parkkonen, M. Petterson, A.H. Berg, P-E. Olsson, and L. Forlin. 1999. Ethinyloestradiol - an undesired fish contraceptive? Aquatic Toxicology 45:91-97.

Leatherland, J. 1992. Endocrine and reproductive function in Great Lakes salmon. Pages 129-145 in T. Colborn and C. Clement, editors. Chemically induced alterations in sexual and functional development: the wildlife/human connection. Princeton Scientific Publishing, Princeton, NJ, U.S.A.

Le Guevel, R., F. Pakdel. 2001. Assessment of oestrogenic potency of chemicals used as growth promoter by in-vitro methods. Human Reproduction 16:1030-6.

Lezama, R. ', A. Díaz-Téllez, G. Ramos-Mandujano, L. Oropeza, and H. PasantesMorales. 2005. Epidermal growth factor receptor is a common element in the signaling pathways activated by cell volume changes in isosmotic, hyposmotic or hyperosmotic conditions. Neurochemical Research 30:1589-97.

Mac, M.J., T. Schwartz, and C.C. Edsall. 1998. Correlating PCB effects on fish reproduction using dioxin equivalents. Presented at the Ninth Annual Society of Environmental Toxicology and Chemistry Meeting, Arlington, Virginia.

Maitre, J-L., Y. Valotaire, and C. Guguen-Guillouzo. 1986. Estradiol-17ß stimulation of vitellogenin synthesis in primary culture of male rainbow trout hepatocytes. In Vitro Cellular and Developmental Biology 22:336-341.

Marlatt, V.L., L.M. Hewitt, and G. Van Der Kraak. 2006. Utility of in vitro test methods to assess the activity of xenoestrogens in fish. Environmental Toxicology and Chemistry 25:3204-3212. 
Martineua, D., A. Lagace, P. Beland, R. Higgins, D. Armstrong, and L.R. Shugart.1988. Pathology of stranded beluga whales (Delphinapterus kucas) from the St. Lawrence estuary, Quebec, Canada. Journal of Comparative Pathology 98:287-311.

Moccia, R.D., J.F. Leatherland, and R.A. Sonstegard. 1981. Quantitative interlake comparison of thyroid pathology in Great Lakes coho (Oncorhynchus kisutch) and Chinook (Oncorhynchus tschauytscha) salmon. Cancer Research 41:2200-2210.

Moccia, R., G. Fox, and A.J. Britton. 1986. A quantitative assessment of thyroid histopathology of herring gulls (Larus argentatus) from the Great Lakes and a hypothesis on the causal role of environmental contaminants. Journal of Wildlife Disease 22:60-70.

Moor, A.N., R. Murtazina, and L. Fliegel. 2000. Calcium and osmotic regulation of the $\mathrm{Na}+\mathrm{H}+$ exchanger in neonatal ventricular myocytes. Journal of Molecular and Cellular Cardiology 32:925-36.

Munoz-Cueto, J.A., E. Burzawa-Gerard, O. Kah, Y. Valotaire, and F. Pakdel. 1999. Cloning and sequencing of the gilthead sea bream estrogen receptor cDNA. DNA Sequence 10:75-84.

Munkittrick, K.R., C.B. Port, G.J. Van Der Kraak, I.R. Smith, and D.A. Rokosh. 1991. Impact of bleached kraft mill effluent on population characteristics, liver MFO activity, and serum steroids of a Lake Superior white sucker (Catostomus commerson) population. Canadian Journal Fisheries and Aquatic Sciences 48:1-10.

Okoumassoun, L.E., D. Averill-Bates, F. Gagne, M. Marion, and F. Denizeau. 2002. Assessing the estrogenic potential of organochlorine pesticides in primary cultures of male rainbow trout (Oncorhynchus mykiss) hepatocytes using vitellogenin as a biomarker. Toxicology 178:193-207.

Orlando, C., P. Pinzani, and M. Pazzagli. 1998. Developments in quantitative PCR. Clinical Chemistry and Laboratory Medicine 36:255-269.

Pakdel, F., S. Feon, F. Le Gac, F. Le Menn, and Y. Valotaire. 1991. In vivo estrogen induction of hepatic estrogen receptor mRNA and correlation with vitellogenin mRNA in rainbow trout. Molecular and Cellular Endocrinology 75:205-212. 
Pelissero, C., G. Flouriot, J.L. Foucher, B. Bennetau, J. Dunogues, F. Le Gac, and J.P. Sumpter. 1993. Vitellogenin synthesis in cultured hepatocytes; an in vitro test for the estrogenic potency of chemicals. Journal of Steroid Biochemistry and Molecular Biology 44:263-272.

Pessonen, M., and T.B. Andersson. 1997. Fish primary hepatocyte culture; an important model for xenobiotic metabolism and toxicity studies. Aquatic Toxicology 37:253-267.

Rankouhi, T.R., I. van Holsteijn, R. Letcher, J.P. Giesy, and M. van der Berg. 2002. Effects of primary exposure to environmental and natural estrogens on vitellogenin induction in carp (Cyprinus carpio) hepatocytes. Toxicological Sciences 67:75-80.

Rasmussen, R., T. Morrison, M. Herrmann, and C. Wittwer. 1998. Quantitative PCR by continuous fluorescence monitoring of a double strand DNA specific binding dye. Biochemica 2:8-11.

Rutishauser, B.V., M. Pessonen, B.I. Escher, G.E. Ackermann, H-R. Aerni, M.J.F. Suter, and R.I.L. Eggen. 2004. Comparative analysis of estrogenic activity in sewage treatment plant effluents involving three in vitro assays and chemical analysis of steroids. Environmental Toxicology and Chemistry 23:857-864.

Reijnders, P.J.H. 1986. Reproductive failure in common seals feeding on fish from polluted coastal waters. Nature 324:456-457.

Sanseverino, J., R.K. Gupta, A.C. Layton, S.S. Patterson, S.A. Ripp, L. Saidek, M.L. Simpson, T.W. Schulz, and T.S. Sayler. 2005. Use of Saccharomyces cerevisiae BLYES expressing bacterial bioluminescence for rapid, sensitive detection of estrogenic compounds. Applied and Environmental Microbiology 71:4455-4460.

Schreer, A. 2005. Application of rainbow trout hepatocyte cultures to study gene expression due to estrogenic chemicals. Doctoral dissertation. Technischen Universitat Dresden, Dresden, Germany.

Segner, H., J.M. Navas, C. Schafers, and A. Wenzel. 2003. Potencies of estrogenic compounds in in vitro screening assays and in life cycle tests with zebrafish in vivo. Ecotoxicology and Environmental Safety 54:315-322.

Shugart, G. 1980. Frequency and distribution of polygony in Great Lakes herring gulls in 1978. Condor 82:426-429. 
Socorro, S., D.M. Power, P-E. Olsson, and A.V.M Canario. 2000. Two estrogen receptors expressed in the teleost fish, Spaurus aurata: cDNA cloning, characterization and tissue distribution. Journal of Endocrinology 166:293306.

Sumpter, J.P., and S. Jobling. 1995. Vitellogenesis as a biomarker for estrogenic contamination of the aquatic environment. Environmental Health Perspectives 7:173-178.

Takagi, M, H. Hayashi, and T. Yoshida. 2000. The effect of osmolarity on metabolism and morphology in adhesion and suspension chinese hamster ovary cells producing tissue plasminogen activator. Cytotechnology 32:171179.

Tan, N.S., T.J. Lam, and J.L. Ding. 1996. The first contiguous estrogen receptor gene from a fish, Oreochromis aureus: evidence for multiple transcripts. Molecular and Cellular Endocrinology 120:177-192.

Tchoudakova, A., S. Pathak, and G.V. Callard. 1999. Molecular cloning of an estrogen receptor $\alpha$ subtype from the goldfish, Carassius auratus. General and Comparative Endocrinology 113:388-400.

Ternes, T. A., M. Stumpf, J. Mueller, K. Haberer, R.D. Wilken R, and M. Servos. 1999.

Behavior and occurrence of estrogens in municipal sewage treatment plants--I. Investigations in Germany, Canada and Brazil. The Science of the Total Environment 225:81-90.

Thellin, O, W. Zorzi, B. Lakaye, B. De Borman, B. Coumans, G. Hennen, T. Grisar, A. Igout, and E. Heinen. 1999. Housekeeping genes as internal standards: use and limits. Journal of Biotechnology 75:291-295.

Thomas-Jones, E., N. Walkley, C. Morris, P. Kille, J. Cryer, I. Weeks, and S. Woodhead. 2003. Quantitative measurement of fathead minnow vitellogenin mRNA using hybridization protection assays. Environmental Toxicology and Chemistry 22:992-995.

Tollefsen, K.E., R. Mathisen, and J. Steenersen. 2003. Induction of vitellogenin synthesis in an Atlantic salmon (Salmo salar) hepatocyte culture: a sensitive in vitro bioassay for the oestrogenic and anti-oestrogenic of chemical. Biomarkers 8:394-407.

Tribe, M.A., and M.R. Eraut. 1979. Hormones. Cambridge University Press, New York, New York, U.S.A. 
Valliant, C., Le Guellec, C., Pakdel, F., and Valotaire, Y. 1988. Vitellogenin gene expression in primary culture of male rainbow trout hepatocytes. General and Comparative Endocrinology 70:284-290.

Wallace, R.A. 1978. Oocyte growth in non-mammalian vertebrates. Pages 465-501 in R.E. Jones, editor. The Vertebrate Ovary. Plenum Corporation, New York, New York, U.S.A.

Wu, M.H., G. Dimopoulos, A. Mantalaris, and J. Varley. 2004. The effect of hyperosmotic pressure on antibody production and gene expression in the GSNS0 cell line. Biotechnology and Applied Biochemistry 40:41-46.

Xia, Z., R. Patiño, W.L. Gale, A.G. Maule, and L.D. Densmore. 1999. Cloning, in vitro expression, and novel phylogenetic classification of a channel catfish estrogen receptor. General Comparative Endocrinology 113:360-368.

Zhou, W., J. Rehm, A. Europa, and W-S. Hu. 1997. Alteration of mammalian cell metabolism by dynamic nutrient feeding. Cytotechnology 24:99-108. 
Table 1: Polar Organic Chemical Integrative Sampler Extract Key

\begin{tabular}{cc}
\hline $\begin{array}{c}\text { Sample } \\
\text { No. }\end{array}$ & Identification \\
\hline 1 & Solvent Control \\
2 & POCIS Control \\
3 & Upper Conococheague Field Blank \\
4 & Lower Conococheague Field Blank \\
5 & Upper Monocacy Field Blank \\
6 & Lower Monocacy Field Blank \\
7 & Blue Plains Field Blank \\
8 & Upper Conococheague POCIS \\
9 & Lower Conococheague POCIS \\
10 & Upper Monocacy POCIS \\
11 & Lower Monocacy POCIS \\
12 & Blue Plains POCIS \\
13 & Solvent Control \\
14 & POCIS Control \\
15 & NFHRL Field Blank \\
16 & Lower Conococheague Field Blank \\
17 & Lower Monocacy Field Blank \\
18 & Upper Conococheague Field Blank \\
19 & NFHRL POCIS \\
20 & Lower Conococheague POCIS \\
21 & Lower Monocacy POCIS \\
22 & Upper Conococheague POCIS \\
\hline
\end{tabular}


Table 2: Applied Biosystems cDNA synthesis Master Mix Formulation

\begin{tabular}{cc}
\hline Reagent & Volume per Tube $(\mu \mathrm{L})$ \\
\hline 10X RT Buffer & 2 \\
25X dNTP Mix & 0.8 \\
$(100 \mathrm{mM})$ & 2 \\
10 RT Random Primers & 1 \\
$\begin{array}{c}\text { Multiscribe } \\
\text { Transcriptase }\end{array}$ & 1 \\
RNase Inhibitor & 3.2 \\
Nuclease -free Water & 10 \\
Total Volume per \\
Reaction
\end{tabular}


Table 3: Applied Biosystems Real-time PCR SYBR Green Master Mix Formulation

\begin{tabular}{cc}
\hline Reagent & Volume per Reaction $(\mu \mathrm{L})$ \\
\hline $\begin{array}{c}\text { 2X SYBR Green PCR } \\
\text { Mix }\end{array}$ & 5 \\
10mM Forward Primer & 0.5 \\
$10 \mathrm{mM}$ Reverse Primer & 0.5 \\
Nuclease-free Water & 4 \\
$\begin{array}{c}\text { Total Volume per } \\
\text { Reaction }\end{array}$ & 10 \\
\hline
\end{tabular}




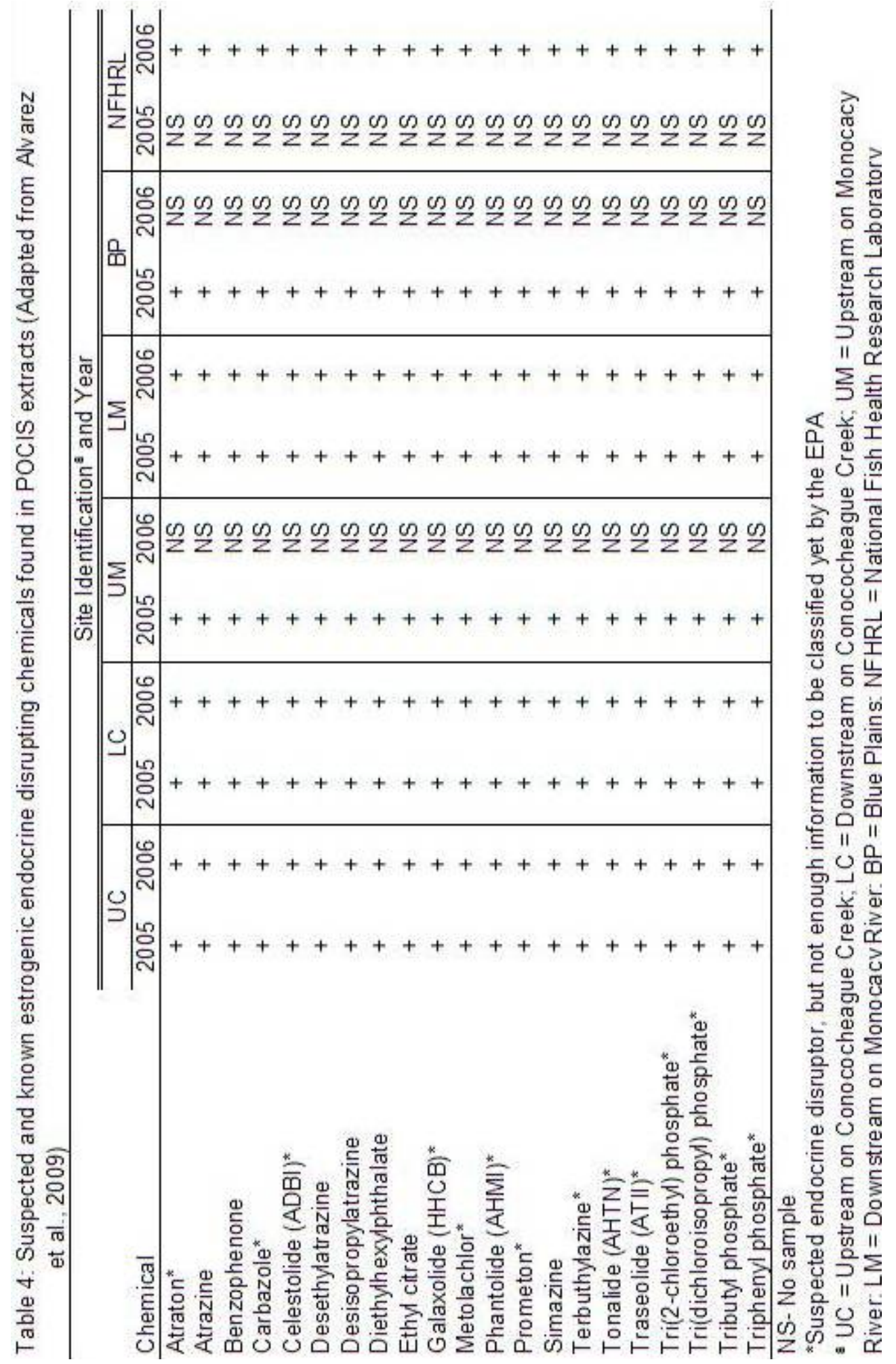




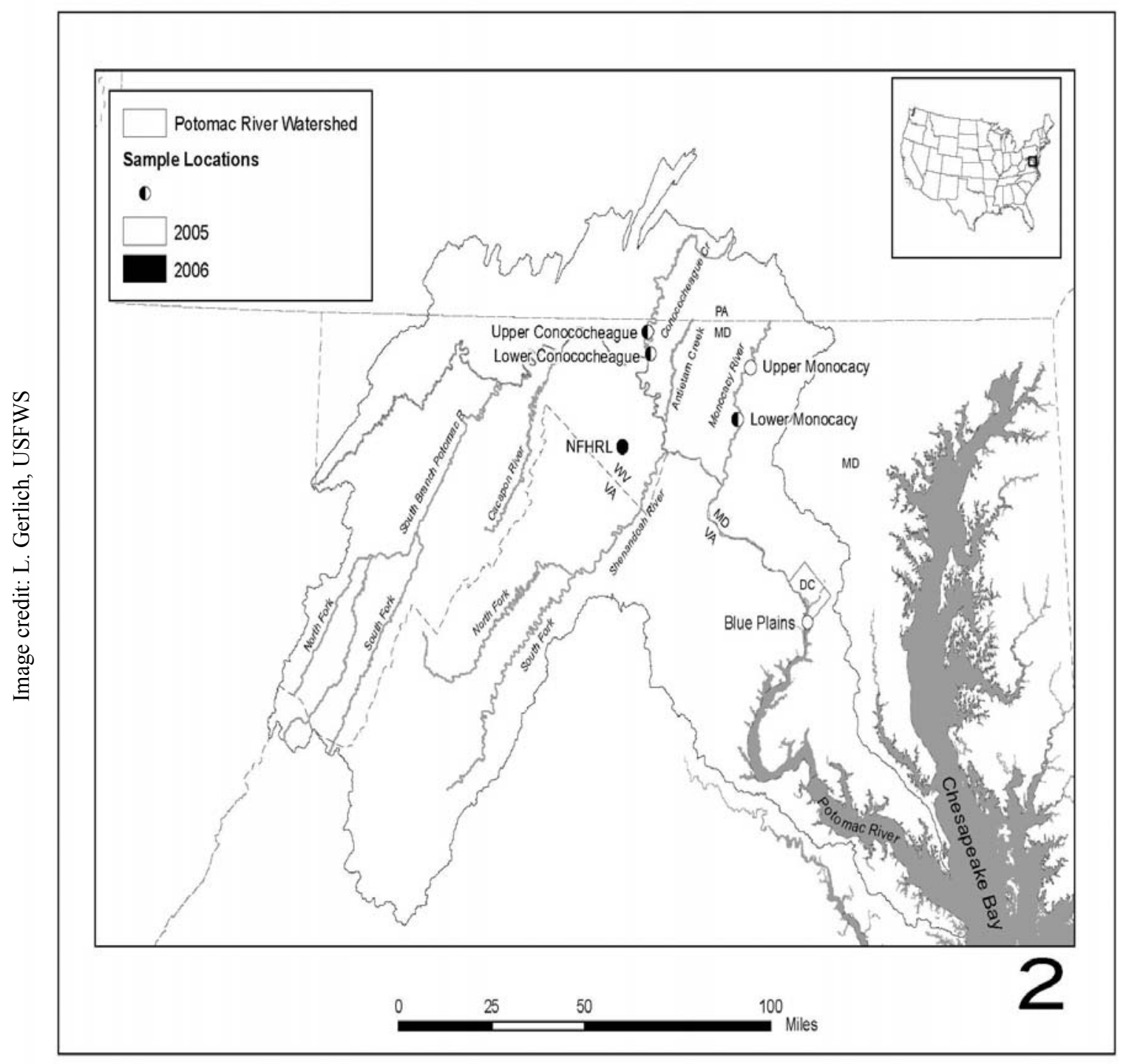

Figure 1: Map of Fall 2005 and Spring 2006 POCIS deployment experimental sites on the Monocacy River and Conococheague Creek and control sites at the USGS National Fish Health Research Laboratory, Leetown, WV and Blue Plains, Washington, D.C. 


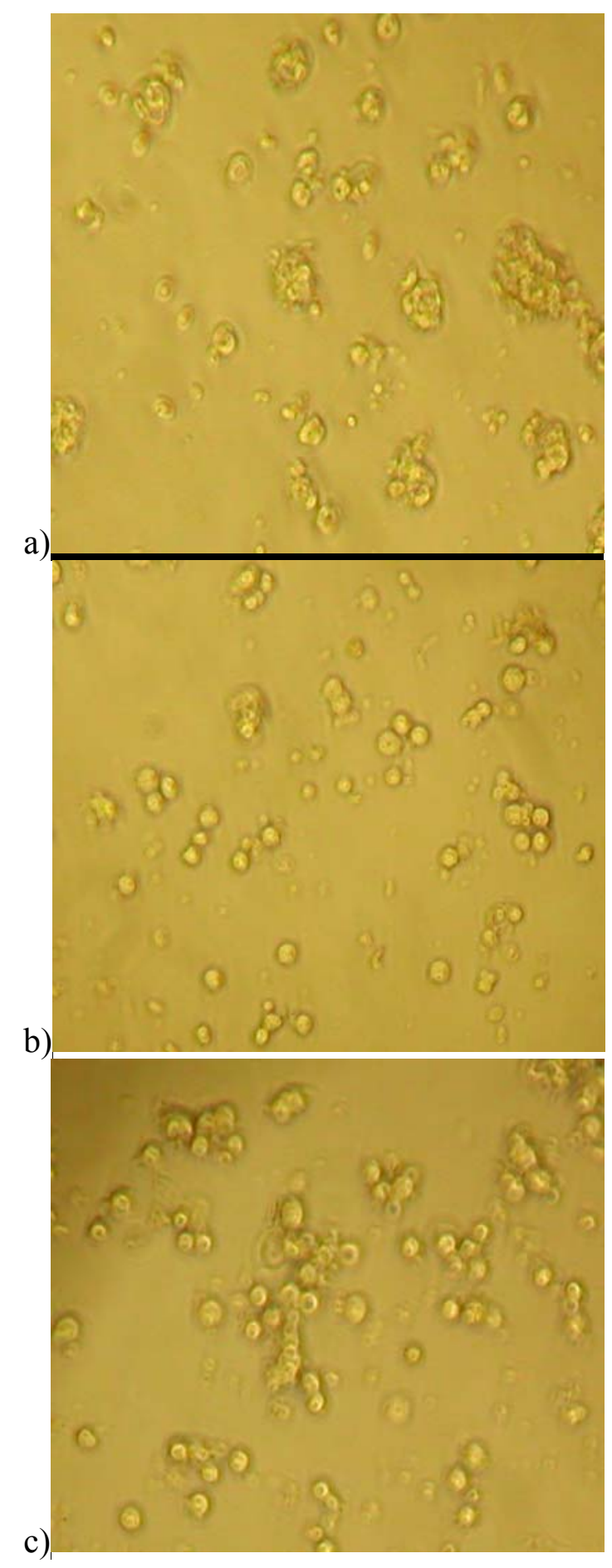

Figure 2: Smallmouth bass hepatocytes in culture in a) L-15, b) William's Medium E, and c) Opti-MEM. 

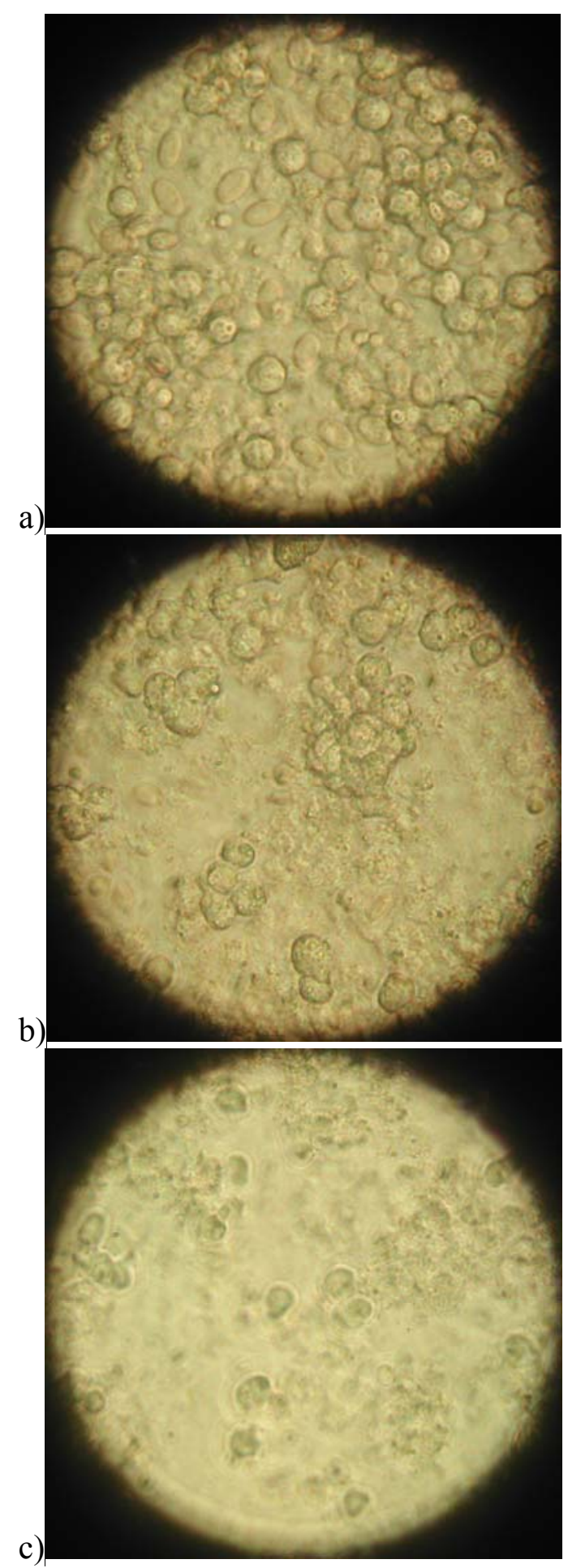

Figure 3: Rainbow trout hepatocytes in culture in a)L-15, b)William's Medium E, and c)Opti-MEM. 


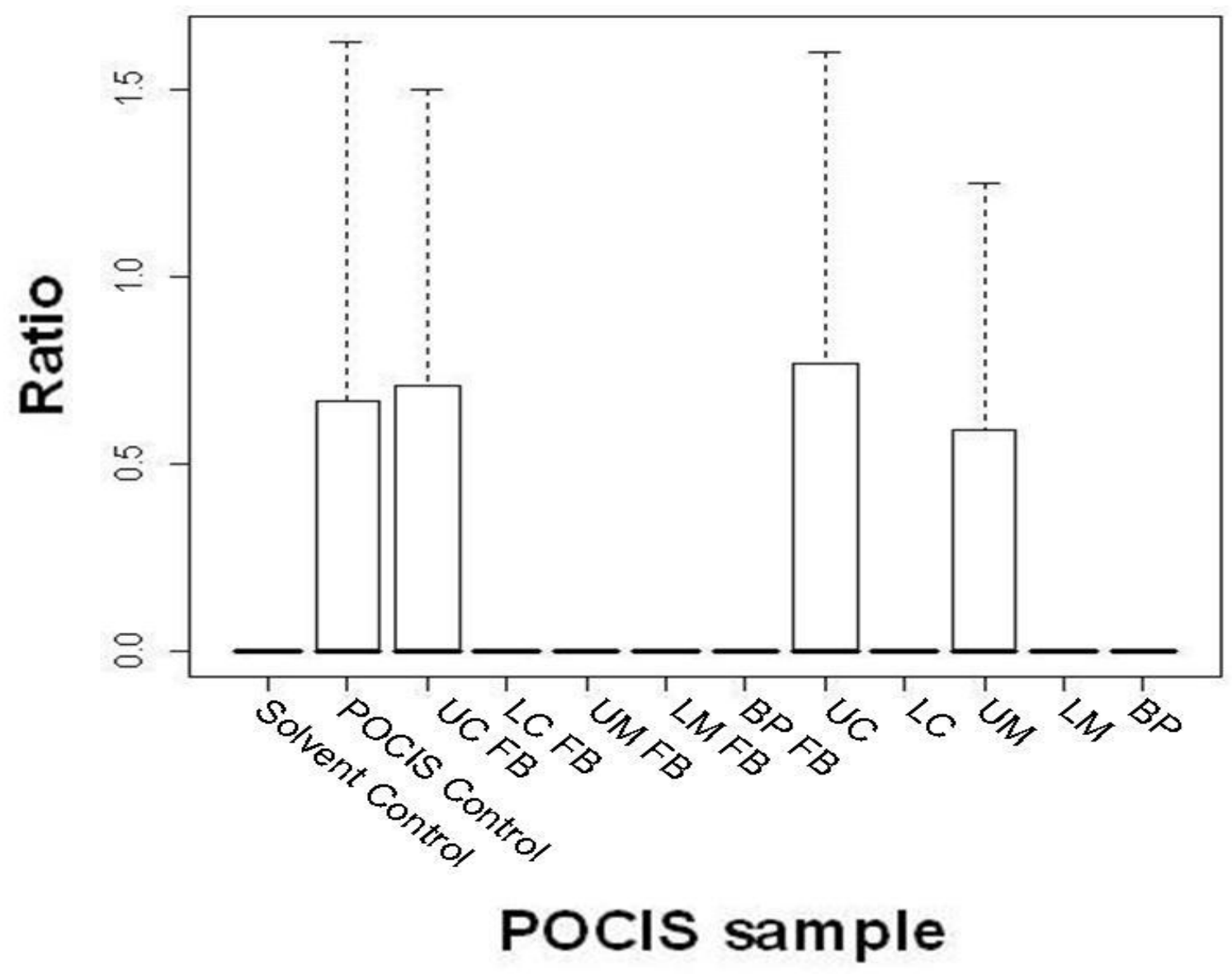

Figure 4: Boxplot of ratios (Vitellogenin/18s) of 2005 POCIS samples. UC=Upstream of WWTP on Conococheague Creek; LC=Downstream of WWTP on Conococheague Creek; UM=Upstream of WWTP on Monocacy River; LM=Downstream of WWTP on Monocacy River; BP=Blue Plains; FB=Field Blank; Error bars represent standard error of the mean. 


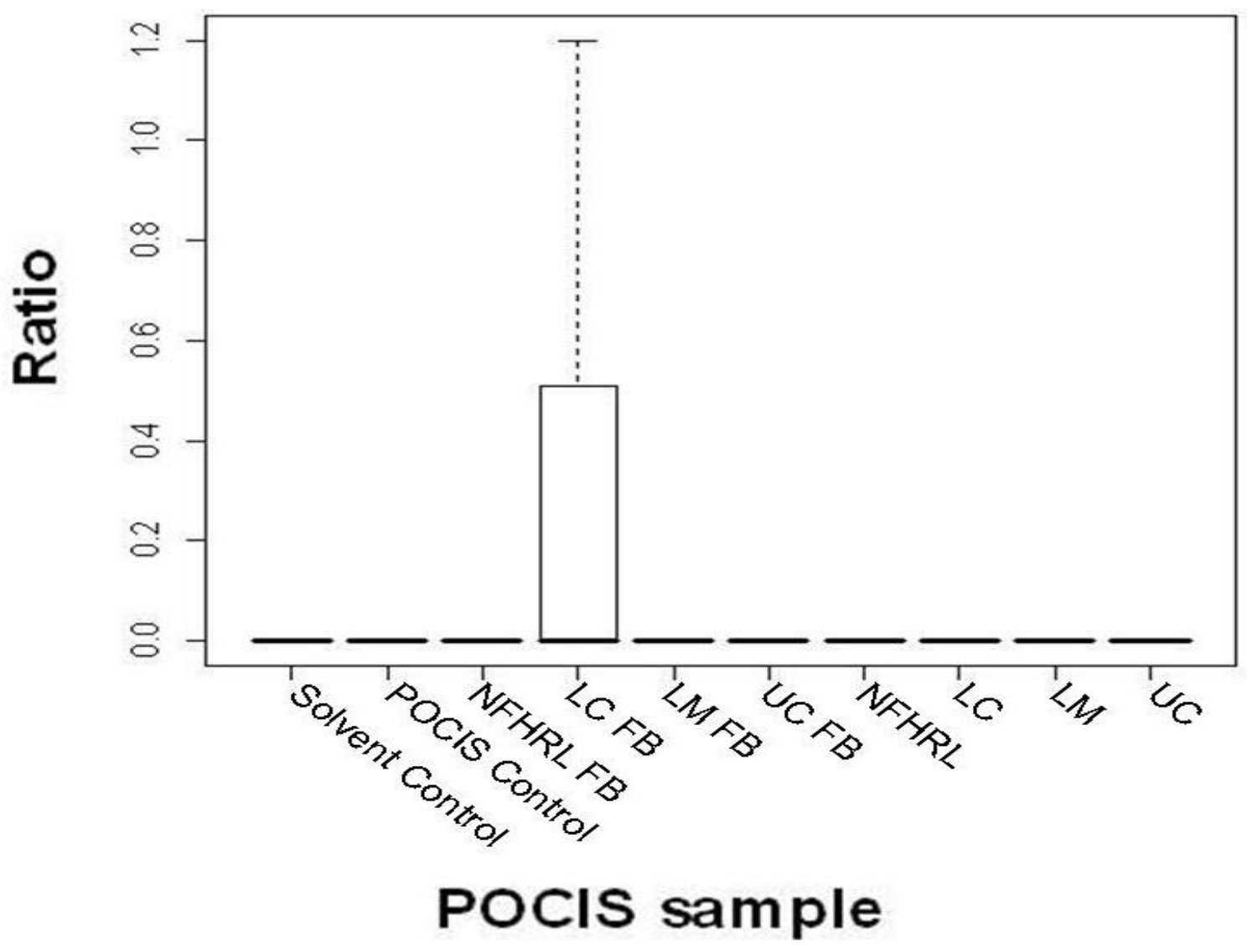

Figure 5: Boxplot of ratios (Vitellogenin/18s) of 2006 POCIS samples. UC=Upstream of WWTP on Conococheague Creek; $\mathrm{LC}=$ Downstream of WWTP on Conococheague Creek; UM=Upstream of WWTP on Monocacy River; LM=Downstream of WWTP on Monocacy River; NFHRL=National Fish Health Research Laboratory, Leetown Science Center; FB=Field Blank; Error bars represent standard error of the mean. 